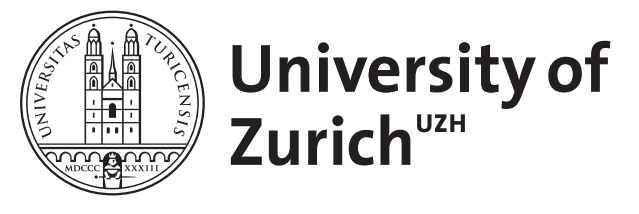

\title{
Caring for ideas
}

Reichenbach, Roland

\begin{abstract}
Education as cultural cultivation includes the practice of caring for ideas. But what is the nature of ideas and what is their role in the educational process? How do ideas relate to ideals? And should (educational) ideas be "put into practice"? Is this possible, and desirable? It is argued in this contribution that we should we be more careful about the role of ideas in the process of education and our lives in general. The paper starts with commentaries on philosophical and etymological backgrounds, and then addresses the question of what makes ideas "successful". Two apparently successful ideas are exemplary discussed, namely, the idea of the nobleness of the heart, and the idea of authentic living. Additionally, the topic is raised how to deal with educational ideas appropriately, and a plea for "modest ideas" is expressed.
\end{abstract}

DOI: https://doi.org/10.30777/apjer.2019.2.2.05

Posted at the Zurich Open Repository and Archive, University of Zurich ZORA URL: https://doi.org/10.5167/uzh-182946

Journal Article

Published Version

Originally published at:

Reichenbach, Roland (2019). Caring for ideas. Asia Pacific Journal of Education Research, 2(2):51-68.

DOI: https://doi.org/10.30777/apjer.2019.2.2.05 


\title{
Caring for Ideas
}

\section{Roland Reichenbach*}

University of Zurich, Switzerland

\begin{abstract}
Education as cultural cultivation includes the practice of caring for ideas. But what is the nature of ideas and what is their role in the educational process? How do ideas relate to ideals? And should (educational) ideas be "put into practice"? Is this possible, and desirable? It is argued in this contribution that we should we be more careful about the role of ideas in the process of education and our lives in general.

The paper starts with commentaries on philosophical and etymological backgrounds, and then addresses the question of what makes ideas "successful". Two apparently successful ideas are exemplary discussed, namely, the idea of the nobleness of the heart, and the idea of authentic living. Additionally, the topic is raised how to deal with educational ideas appropriately, and a plea for "modest ideas" is expressed.
\end{abstract}

\section{Keywords}

caring for ideas, educational ideas, ideals, authenticity, comparative education

\footnotetext{
* Corresponding author

Institute of Educational Science, University of Zurich, Zurich, Switzerland

Email: roland.reichenbach@ife.uzh.ch
}

\section{Acknowledgement}

I would like to express my gratitude to Daniel Werner (University of Zurich) who translated the German manuscript. 
In the epilogue of his Personal Impressions, Isaiah Berlin wrote the following: "My interest in ideas, my belief in their tremendous and sometimes disastrous power, my conviction that man, if he does not comprehend these ideas fully, is threatened by them much more than by the uncontrolled forces of nature or by his own institutions - all this is confirmed by what is going in the world on a daily basis." (2001, pp. 372 f.).1) Ideas are more than innocent thought bubbles; they are able, when becoming relevant, to trigger off effects that influence life and living together positively as well as negatively. They may, if they become full of "passionate enthusiasm" ("leidenschaftlicher Überschwang"), to cite Berlin again, lend wings to the arts and destroy life (p. 375).

In the following, a commentary to the philosophical backgrounds of etymology is presented, then the topic of what makes ideas "successful" is addressed, and then, using, among others, the example of the idea of education, how to think of dealing with ideas in a reasonable manner is discussed. Some brief remarks on "modest" ideas complete the contribution.

\section{Etymological and Conceptual Comments}

In colloquial speech, the term idea is used in the sense of the meaning of "thoughts," "imagination," "notion," "model," or "ideal," while the classical Greek idéa originally refers back to figure or form and also to the archetype, respectively. "Idea" is a transliteration of a Greek term that originally refers back to seeing and recognizing forms or shapes (cf. Urmson, 1967, p. 118). In Plato's Republic, the "idea of the good" is presented as the "the highest subject of knowledge" (Plato, 1961, p. 257). In his so-called theory of ideas (or theory of forms), ideas act as eternal archetypes of things. Immanuel Kant offers a specifying comment on Plato: "For him, the ideas represent the archetypes of things in themselves and not only the keys to possible experiences as the categories," and "with no literary analysis, in order to perceive the meaning that the noble philosopher related to his phrase." (1975, p. 142, translated by D. W.).2) In the

1) German version: "Mein Interesse an Ideen, mein Glaube an ihre gewaltige und manchmal unheilvolle Macht, meine Überzeugung, dass der Mensch, wenn er diese Ideen nicht richtig begreift, von ihnen viel stärker bedroht wird als von den unkontrollierten Naturgewalten oder auch seinen eigenen Institutionen - all das wird von den Vorgängen in der Welt tagtäglich neu bestärkt".

2) German original: "Die Ideen sind bei ihm Urbilder der Dinge selbst und nicht bloss Schlüssel zu möglichen Erfahrungen wie die Kategorien," yet, according to Kant, he does want to engage ,in keine literarische Untersuchung $[\cdots]$, um den Sinn auszumachen, den der erhabene Philosoph mit seinem Ausdrucke verband”. 
history of philosophy, the platonic perspective has been dealt with or problematized in the Universalienstreit ("problem of universals"; cf. de Libera, 2005). As objects of the mind, ideas are contradistinctive to "mere" objects of perception and relate to - especially from a platonic perspective - the state and the essence of things as they exist "truly" and as entities independent from the empirical world. While ideas can be understood as "universals" in this manner, there is already a notion with a slightly different emphasis in Plato's work also, namely that of the idea as a pragmatic form that finds its expression as imitations or incomplete and deficient copies in the world of concrete phenomena (Urmson, 1967, p. 118). As a result, there is a certain degree of thematic tension that arises between the understanding of ideas as pure universals on the one hand and the understanding of ideas as similarities whose access is made possible in the and through the phenomenal world on the other hand.

As eternal and independent paradigms, ideas receive the status of God's though in Christian theology, and understood as a pattern, design, or plan, the concept of the idea finds a home as well in the minds of men, to some extent, in medieval theology (cf. Leppin, 2007). The two meanings - idea as mental thought and idea as pattern or example of an object or phenomenon - are not, however, disconnected from each other; moreover, they coincide eventually in the notion of the idea as a "mental representation." The image- or imagery-character of the idea and the ideational or ideal (imagined as exemplary status as well) remains the same due to the existing and nuanced differences.3) Different philosophical perspectives and attitudes regarding the nature of ideas concern epistemological questions and differences of origin (of ideas and the ideal) as well as of the ontological status; for the main part, rationalistic, empiristic or sensualistic, yet also nativistic positions are or were facing each other here. The questions if and/or to what extent ideas are "inherent," "universal," "independent," "eternal," "abstract," or yet "concrete" and "culturally bound" may be taking a back seat today - at least, if it concerns the significance and effect of ideas in human actions and coexistence.

In his Kritik der reinen Vernunft (Critique of Pure Reason), Kant argues: "For me, the idea represents a necessary concept of reason to whose meaningfulness no coinciding object can be offered [...]. They are concepts of pure reason; since they contemplate all insights of experience as determined by an absolute totality of

3) "Idee bedeutet eigentlich einen Vernunftbegriff, und Ideal die Vorstellung eines einzelnen als einer Idee adäquaten Wesens," differentiates Kant in his Kritik der Urteilskraft (Critique of Judgment; 1991, p. 114; "Idea rather signifies a concept of reason and ideal the imagination of a single entity adequate to an idea."). 
conditions. They are not made up deliberately, but given to reason itself by nature and, therefore, refer to using the full intellect necessarily." (1975, p. 147, translated by D. W.).4) Ideas as "transcendental concepts of reason" are "just ideas", but therewith not all "superfluous" ("überflüssig") or "invalid" ("nichtig", p. 149), instead they serve the different forms of intellect - i.e. the empirical use of intellect (p. 207) - "mostly unnoticed" as guidelines ("canon") and thereby help to lead the cognitive process (p. 149). As such "regulative principles," ideas offer larger unities than the empirical use of intellect ever could achieve, which also means that they enable insights to be gained from contradictions and quarrels (of intellect) through "admittedly brilliant, yet treacherous semblance" ("zwar glänzenden, aber trügenden Schein") as well as "persuasions and imagined knowledge" (ibid.). As a result, the productive negativity of the practice relating to the critique of reason finds expression. It is, according to Hannah Arendt in her reading of Kant, solely " "the negative that represents the actual enlightenment.' Enlightenment signifies [...] being exempt from prejudices, authorities, it signifies a purging act"; 1998, p. 47; translated by D. W.),5) leaving the "cave of opinions" ("Höhle der Meinungen" p. 76). In contrast to the intellect, reason does not solve problems; reason rather helps to irritate and derange beliefs that cannot withstand enlightening critique. On the other side, a rational idea cannot be confirmed by pure empiricism.

The aesthetic idea serves as a complimentary concept to the rational idea for Kant: "[B]ut an aesthetic idea, for me, is the notion of imagination that instigates a lot of thinking without there being a specific thought, i.e. term, that is adequate, which no language fully reaches and can make comprehensible by implication (1991, p. 246, translated by D. W.).6) It is easily discernible "[T]hat it is the counterpart (pendant) of a rational idea, which in turn is a term that has no adequate perception (notion of imagination (ibid.; transl. D. W.). ${ }^{7)}$ In doing so, the idea's imagery or "imaginedness"

4) German original: "Ich verstehe unter der Idee einen notwendigen Vernunftbegriff, dem kein kongruierender Gegenstand in den Sinnen gegeben werden kann $[\cdots]$. Sie sind Begriffe der reinen Vernunft; denn sie betrachten alle Erfahrungserkenntnis als bestimmt durch eine absolute Totalität der Bedingungen. Sie sind nicht willkürlich erdichtet, sondern durch die Natur der Vernunft selbst aufgegeben und beziehen sich daher notwendigerweise auf den ganzen Verstandesgebrauch".

5) German original: “'das Negative welches die eigentliche Aufklärung ausmacht.' Aufklärung meine [...] Befreiung von Vorurteilen, von Autoritäten, meint einen reinigenden Vorgang".

6) German original: "[U]nter einer ästhetischen Idee aber verstehe ich diejenige Vorstellung der Einbildungskraft, die viel zu denken veranlasst, ohne dass ihr doch irgendein bestimmter Gedanke, d.i. Begriff, adäquat sein kann, die folglich keine Sprache völlig erreicht und verständlich machen kann".

7) German original: "dass sie das Gegenstück (Pendant) von einer Vernunftidee sei, welche umgekehrt ein Begriffist, dem keine Anschauung (Vorstellung der Einbildungskraft) adäquat sein kann”. 
("Imaginiertheit") is emphasized - in contrast to the "rational idea" or also the "transcendental idea"; a difference that is not to be found in the platonic doctrine of forms in this firm manner. Aesthetic ideas give language and form to experience that it could not offer from within by itself. „Such a notion of imagination can be called ideas: on the one hand, therefore, since they, at least, strive for something that lies beyond the boundaries of experience and thus try to come near a representation of the concepts of reason (of the intellectual ideas) what gives them the semblance of an objective reality; on the other hand and indeed primarily, since there is no completely adequate term for them as inner perceptions." (ibid., p. 246 f.; transl. D. W.). ${ }^{8)}$ In this context, Kant puts a special emphasis on the importance of poetry or the poets at this point in his Kritik der Urteilskraft (Critique of Judgment): The poet dares to sensualize rational ideas of invisible entities, the realm of the blessed, hell, eternity, creation and suchlike; or also that which finds indeed examples in experience, e.g. death, envy and all vices, also love, glory and suchlike, beyond the limitations of experience, by means of an imagination that tries to equal the foreplay of reason in order to reach the highest level to sensualize it in a completeness for which there exists no example in nature; and essentially, it is poetry in which the capability of aesthetic ideas can show itself to its full extent. Yet, this capability, regarded individually, is only a talent (of imagination)." (ibid., p. 247, transl. D. W.).9)

Following these philosophical contemplations on the essence of the idea that referred to two essentially pertinent approaches, the next part addresses a contemporary understanding of the concept.

8) German original: "Man kann dergleichen Vorstellung der Einbildungskraft Ideen nennen: einesteils darum, weil sie zu etwas über die Erfahrungsgrenze hinaus Liegendem wenigstens streben, und so einer Darstellung der Vernunftbegriffe (der intellektuellen Ideen) nahe zu kommen suchen, welches ihnen en Anschein einer objektiven Realität gibt; andererseits, und zwar hauptsächlich, weil ihnen, als innern Anschauungen, kein Begriff völlig adäquat sein kann".

9) "Der Dichter wagt es, Vernunftideen von unsichtbaren Wesen, das Reich der Seligen, das Höllenreich, die Ewigkeit, die Schöpfung u. dgl. zu versinnlichen; oder auch das, was zwar Beispiele in der Erfahrung findet, z.B. den Tod, den Neid und alle Laster, imgleichen die Liebe, den Ruhm u. dgl. über die Schranken der Erfahrung hinaus, vermittelst einer Einbildungskraft, die dem Vernunft-Vorspiele in Erreichung eines Grössten nacheifert, in einer Vollständigkeit sinnlich zu machen, für die sich in der Natur kein Beispiel findet; und es ist eigentlich die Dichtkunst, in welcher sich das Vermögen ästhetischer Ideen in seinem ganzen Masse zeigen kann. Dieses Vermögen aber, für sich allein betrachtet, ist eigentlich nur ein Talent (der Einbildungskraft)". 


\section{“Successful” Ideas - Two Examples}

Ideas may have effects or they might remain inoperative to a large extent. Ideas are only in so far effective as they are shared by (enough) people - be that more or less implicit or yet articulated -, as they are, in a sense, able to "spread," and find a place in the hearts and minds of people. According to Eva Illouz, successful ideas have to fulfill at least three conditions: (1) They have to "match" the social situation, i.e. to explain the experiences of the social actors to themselves among other things. (2) They have to offer orientation, especially in the areas of life that are deemed as important, and (3) they "have to be institutionalized in social networks and circulate"; 2009, p. 41). This is not possible without exhibiting appropriate qualities regarding comprehensibility and simplicity of the thought transported as idea. In this context, the imagery or clarity and/or the metaphoric persuasiveness play an important role above all. In effect, the force of the repetition hammer joins in and a certain "memetic contamination." What is the meaning of this? You may look at pictures, read words, or hear melodies and contemplate; yet, in secret, you will become, so to speak, "infected" by these perceptions and do not notice the contamination, maybe not even later on (cf. Sebök, 2008, p. 196) - or it is compared with education and subjectivity. The parasitic culture of memes, as Sebök states it based on Daniel Dennett's idea of "mimetics," consists of ideas and fragments of ideas that you encounter choosing people, in a sense, as hosts and striving for one thing only basically, namely being copied. Memes (i.e. ideas) can be stronger than genes: "The memes regarding suicide, celibacy and vows of virginity are viable, although they are hardly consistent with the imperative of our genes" (ibid., p. 206, transl. D. W.). ${ }^{10)}$

How do the nature of genes and the culture of memes interact with each other? Maybe like this: Humans may be constructed as "gene machines," yet they are rather educated and socialized as "meme machines" (cf. ibid., p. 210). Individuality itself the authentic lifestyle - is one these successful modern memes that have spread far and wide over the globe; it represents a political, psychological, and pedagogical idea (infection) which is highly significant and resilient. The virus may change, yet its core is amazingly stable: It is the idea that living your own life is possible. "To live your own life" is, of course, still not a universally accepted ideal.11)

10) German original: "Die Meme des Selbstmords, des Zölibats und des Jungfräulichkeitsgelübdes sind lebensfähig, obwohl sie mit dem Imperativ unserer Gene kaum vereinbar sind".

11) The Indian-British psychoanalyst Sudhir Kakar describes a scene that happened in India in an interview (von Thadden, 
In the following, two examples of "successful" ideas are illustrated in more detail: the idea of nobleness of the heart and the idea of authentic living.

\section{The Idea of Nobleness of the Heart}

It is difficult to imagine that ideas become successful if they are not useful or helpful in explaining experiences, i.e. making them perceptible, to humans as self-interpreting animals (cf. Taylor, 1985). In addition, imagery or metaphorical content are, as mentioned, extremely important. Admittedly, the use of metaphors represents "inauthentic" talk, quasi the acknowledgement that the objective portrayal of reality is not possible in human affairs, yet we have no choice but to find an expression for our thoughts, desires, and feelings with which we are able to convey ourselves to ourselves and to others. For example, we understand what is meant by expressions like "nobleness of the heart," "matter of the heart," "cold," "soft," or "big" heart, we understand the meaning of "stout-hearted" actions, and so forth. The use of the heart metaphor is by no means pure emotional imagery, even in its somewhat modest, yet significant forms, e.g. the "broken" heart or the idiom "with heart and soul." Instead, an idea is transported with or through its use that explains the nature of humans or how they should have to be. In Greek antiquity, the heart was ascribed the seat of the soul for some time. Thereafter, the soul changed its place of residence and moved to the brain for a couple of centuries. Yet with Franz Brentano (1838-1917), at the latest, whose philosophical studies on psychology and psychological analyses of philosophy influenced Edmund Husserl, Alexius von Meinong, and, of course, Sigmund Freud, the soul has left the brain as well and then the body in general after all and is now regarded as a phenomenon of the body only, respectively. According to Brentano already in the $19^{\text {th }}$ century, psychology, as a matter of fact, has nothing to contribute regarding the soul, but still something regarding psychical phenomena. This is no small thing, although psyche signifies only "wisp" or "breath" in classical Greek, but the draft of air continues to remain significant as a metaphor for life or soul and it gives psychology its name to this day. Yet, who examines the phenomena of the soul does not examine the soul itself; who questions the use of the heart metaphor does not observe the heart - it is rather about the cultural awareness of soul in the first place.

2005): A married couple visited him in his office with their daughter: The daughter, so the father, suffers from this disease that is called "autonomy" in Europe; his daughter was actually under the impression that she herself knows what is best for her; and would it be possible for him, Kakar, to help the family? 
The idea of nobleness of the soul refers to the manner in which the individual conducts his- or herself in respect to itself and the outside world, how it deals with itself and the outside world, and which habits it develops in doing so. Alexis de Tocqueville, who should have analyzed and described the developments in the "New World" on behalf of the postrevolutionary French government, used the nice expression "habits of the heart" ("habitudes de cœur") in the second volume of his work Democracy in America (Über die Demokratie in Amerika), published between 1835 and 1840 (Tocqueville 1987). With this expression, he refers to attitudes, customs, and rituals that should prevent from the consequences which may entail the disappointed control illusions inherent in democratic communities. In contrast to authoritarian constitutions, there are dangers within the soft despotism of democracy that should be and also have to be met on the level of emotional development. Therefore, nobleness of the heart is not a private matter for de Tocqueville and it does not only or primarily concern the individual. ${ }^{12)}$

Based on the example of the heart metaphor, it becomes apparent how persistent and practically significant ideas can be.

\section{The Idea of Authentic Living}

A second example concerns the ideational influence of the so-called humanistic psychology. Carl Rogers has to be regarded as one of the key figures of popularizing psychology certainly. The fundamental basis for his "success" is a "substantially simplified Freudian theory" (Illouz, 2009, p. 267) that has been able to turn the fatalistic determinism and cultural pessimism of classical psychoanalysis into its "American-optimistic" opposite. Rogers 'theory (Rogers, 2005, 2007) is based on the "simple idea of a tendency for self-realization, understood as a motivation inherent in every lifeform to develop its potential to the greatest extent possible." (Illouz, 2009, p. 268, transl. D. W.). The good news and the implicit purpose consists in the voluntaristic premise, according to which "each crisis [gives] the self the opportunity to grow and to master the world" (ibid.). Psychology, i.e. what is assumed as psychology or what has become used to act as such in a rather immodest way, was able to affiliate itself through the doctrine of growth and development with the impressive ethos

12) Helena Flam states in Soziologie der Emotionen ("Sociology of Emotions;" 2002) that political power can also be seen in controlling and influencing emotional reactions of citizens. This power may dwindle and might be lost completely, as any kind of power does. 
of self-help rooted in the USA and to establish a perspective, according to which "growth and maturity were inherent parts of life" "that would be achieved through conscious force of will" (ibid.) ${ }^{13)}$ While humans were to be understood as morally good in principle and natural development as sound in principle from the romantic standpoint, the mental and psychic health could be regarded as a general case of human development at the same time. As a consequence, to be healthy means to (be able to) develop one's potential as much as possible at any time - to be "fully alive," as Rogers and Freiberg (1994) state, to be a "fully functioning person" and for a teacher, to be "fully alive in the classroom," for example (cf. Rogers, 1969; Rogers \& Freiberg 1994).

The therapeutic ethos formulates and norms the idea and the ideal of authentic living. In doing so, it is crucial that the need for self-realization is understood as original and natural and not in the least as a secondary need and as culturally contingent. Through this "natural" developmental guideline, however, the individual is also bound to be a free actor: It would be "a mistake" if individuals would refrain from "making the best out of every moment of their existence and to justice to this existence in the way it was given to them" (Illouz, 2009, p. 269). Who gets left behind the psychological ideal of self-realization is - as a matter of degree - to be regarded as "invalid" in the end. Abraham Maslow, who was groomed, so to speak, by Rogers, states accordingly: "We call individuals 'insane' who are not themselves, the individuals who have built every neurotic barrier imaginable not to be human." (cit. in ibid., p. 270, transl. D. W.). The happy and normal life is the self-realized life.

The power of the idea of authentic living leads to the maxim: "I am okay and deserve to be happy" (cf. Wilson, 2009 p. 143). The therapeutic discourse is performative in this context; it does not "only" alter the understanding of self- and of social relations, but rather these relations themselves. Discourses have a performative character if they are able to designate and alter reality in their own right and if those individuals who take part in these discourses stand for the "symbolic capital" of the group that they represent (cf. Illouz, 2009, p. 102). Whereas normality still represented an "extremely mentally fragile condition, the end result of a complex and rather rare maturing process" (ibid., p. 81), for Freud, the happy life acts as the normal life today, the unhappy life as the invalid life. The success of the therapeutic ethos has to be brought into question also as a side effect of democratization as well as its

13) German version: "Wachstum und Reife [seien] inhärente Bestandteile des Lebenslaufs, “,die durch bewusste Willensakte zu erreichen wären". 
psychopathological basics - i.e. the new, at the same time socially acceptable as well as more sensitively perceived psychological suffering (to suffer more consciously and not have to tolerate suffering). Psychological suffering and disorders - neglected childhood, lack of self-esteem, workaholism, sexual disorders, diverse experiences of abuse of different, various phobias and much else - are quasi "democratic, since they can no longer be attributed to a [specific] class"; ibid., p. 68).14)

\section{On How to Deal with Ideas Appropriately - the Example of Education}

Ideas do not - even and especially as regulative main ideas - represent truths and realities; as products of the imagination, they rather help to structure the perception of reality and to provide orientation regarding actions. In doing so, they might sharpen and support the attention to what is true, appropriate, and decent as well as the attention to the common world. Ideas are not born out of nothingness, their creation is definitely governed by - speaking from a cognitive psychological standpoint - our (mental) concept system, but also - and this appears to be of greater importance - by the underlying cultural assets of self-conception and the metaphorical conditions regarding our possibilities to describe ourselves that are connected to them.

For the most part, no specific idea can hold more truth than any other idea. Analogous to metaphors, nevertheless, that typically put an emphasis on aspects while others are moved to the background or hidden completely (Lakoff \& Johnson, 2000), however, ideas represent the expression of possible points of view and orientation. The goals connected to this - e.g. in the conflict between the idea of freedom and the idea of equality "conflict with one another from time to time: In many cases, there are tormented decisions regarding one thing or another and coming to unpleasant compromises"; Berlin, 2001, p. 374). That the ideals connected to the ideas cannot be achieved or realized - or not easily or as desired - is part of the normal or else bitter experience of human kind. The question is how to deal with this shortcoming. Whether the inaccessibility and practical incapability of the idea argue for or against the high ideal or the beautiful idea in reality may be debatable - a condition that might not ever change. Berlin states somewhat bitterly or ironically: "There is always something

14) In contrast to epidemiology, etiology, and psychopathology at the beginning of the $20^{\text {th }}$ century. 
that prevents the ideal's realization here on earth," and "Since, apparently, you only need to remove this one obstacle from humanity's path, no sacrifice, therefore, can be big enough, as long as you advance towards the goal only in this manner. No believe has brought more violence, oppression, and misery over mankind. With the demand that the real present must be sacrificed for an ideal future that can be achieved, the worst cruelties were tried to be justified" (2001, p. 373).15) To endure an incomplete life and a world that could and also should always be better as it is may seem apolitical, but it is perhaps just one of the most important and also political virtues. Because there is always a mistake: "However you wanted to imagine a permanent condition, even under conditions of perfected knowledge: there is always something wrong because of the infinite and constant change of all conditions." (Jaspers, 2013 p. 368, transl. D. W.). ${ }^{16)}$ There is no surprise, therefore, that Berlin chose Kant's accordingly beautiful expression as the title of his book on the history of ideas, The Crooked Timber of Humanity (1990), particularly the part of the original that runs as follows: "[O]f such crooked wood, of which man is made of, nothing fully straight can be timbered. Only the approximation to this idea is inflicted upon us by nature [...]." (Kant, 1975 p. 41, transl. D. W.). ${ }^{17)}$

The "crooked timber of humanity" could also influence and promote the way in which the idea of education is dealt with. The culturally so comprehensive notion of the developmental task of humanity and its personification could cause the appreciation and further cultivation of this wealth of ideas. The US-American educational philosopher Nel Noddings (1992) used - albeit in a somewhat different context - the expression "caring for ideas." Ideas need care. It is not so much a question of wanting to realize them compulsively, but rather a question of getting to know and appreciate their manifold orientation functions in describing the world (also of education and upbringing). The majority of superficial talk and spiteful disputes would, thereby, become superfluous, since the futility of this course of action can be recognized in

15) German version: "Immer gibt es etwas, das die Verwirklichung des Ideals hier auf Erden verhindert. Da man offenbar nur dieses eine Hindernis aus dem Pfad der Menschheit zu entfernen braucht, kann folglich kein Opfer zu gross sein, solange man nur so dem Ziel näher kommt. Kein Glaube hat mehr Gewalt, Unterdrückung und Leid über die Menschen gebracht. Mit der Forderung, die reale Gegenwart müsse einer erreichbaren idealen Zukunft geopfert werden, hat man die schlimmsten Grausamkeiten zu rechtfertigen gesucht".

16) German original: "Wie auch immer man sich einen Dauerzustand vorstellen wollte, selbst unter Voraussetzung vollendeter Erkenntnis: stets stimmt etwas nicht wegen der Endlosigkeit aller sich unablässig wandelnden Bedingungen".

17) German original: "[A]us so krummen Holze, als woraus der Mensch gemacht ist, kann nichts ganz Gerades gezimmert werden. Nur die Annäherung zu dieser Idee ist uns von der Natur auferlegt [...]". 
doing so. Who would like to deny, for example, the significance of the idea of "negativity" for the understanding of education, which finds expression with Socrates who acts, therefore, as prototype, so to speak, of the idea of enlightenment. Arendt paraphrases this though as follows:" "If the winds of thought that I will awaken in you now have roused you from your sleep and made you feel fully awake and alive, then you will think that you have nothing in your hands but perplexity, and what is best still is to make it our common cause." (Arendt, 1998, p. 174 f.; transl. D. W.). ${ }^{18)}$ Who would and could want to offer a completely different idea of education or to describe it as more correct or useful in opposition to the one that Wilhelm von Humboldt put at the center of consideration: "The correlation of our self with the world seems to be, at first glance maybe, not only an incomprehensible expression, but also an overextended thought. Upon closer examination, however, at least the last doubt will vanish and it will become clear that if you find the true pursuit of the human intellect (that what contains its highest spark as well as its most powerless endeavor), it is impossible to be content with anything of a lesser quality" (1969, p. 29).19) How could you deny, to give another example, the significance of work for the expression of experience in this context - a focus set by the French philosopher Marcel Gauchet: "Learning how to read does not only mean to familiarize oneself with written symbols, but also to be captured by a world that has been there prior to us in full armor and defends the overall context to the furthermost corner; the solution is to come across a binding order that offers final orientation when meeting others and defining one's own standpoint by, starting at the lowest level, gradually giving form to human experience through working on the expression. At this point, it is truly appropriate to talk about culture." (cit. and trans. in Foray, 2007, p. 624, transl. D.W.).20)

This and many other ideas do not compete with each other, however, they do not

18) "Wenn dich der Wind des Denkens, den ich jetzt in dir erwecken werde, aus dem Schlaf geweckt und völlig wach und lebendig gemacht hat, dann wirst du erkennen, dass du nichts in der Hand hast als Ratlosigkeit, und das Beste ist immer noch, sie zu unserer gemeinsamen Sache zu machen.

19) German original: "Die Verknüpfung unsres Ichs mit der Welt scheint vielleicht auf den ersten Augenblick nicht nur ein unverständlicher Ausdruck, sondern auch ein überspannter Gedanke. Bei genauerer Untersuchung aber wird wenigstens der letzte Verdacht verschwinden, und es wird sich zeigen, dass, wenn man einmal das wahre Streben des menschlichen Geistes (das, worin ebenso sein höchster Schwung als sein ohnmächtigster Versuch enthalten ist) aufsucht, man unmöglich bei etwas Geringerem stehen bleiben kann".

20) German version: "Lesen zu lernen, heißt nicht allein, sich mit nützlichen schriftlichen Zeichen vertraut zu machen, sondern auch von einer Welt erfasst zu werden, die in voller Rüstung schon vor uns da war und noch im hintersten Winkel für den Gesamtzusammenhang einsteht; es heißt, auf eine bindende Ordnung zu treffen, die letzte Orientierung bietet bei der Begegnung mit anderen und der eigenen Standortbestimmung, indem vom niedrigsten Niveau an über die Arbeit am Ausdruck der menschlichen Erfahrung nach und nach eine Form gegeben wird. Hier ist es wirklich einmal voll und ganz angebracht, von Kultur zu sprechen". 
form a beautiful entirety either; they rather help us to understand and address education in different ways. In doing so, the fact that this discourse does not represent an occidental and, by no means, a German exclusivity has sometimes been forgotten. There is, for example, an old movement in the Confucian way of thinking that seeks to understand education as quest or exploratory movement of mankind. In Mengzi (resp. Mencius, 370-290 BC), the following part on the nobleness of the heart (xinxue) can be found: "Duty is the natural way of mankind. How sad it is, if you leave your way and do not walk on it, if you lose your heart and you do not know how to find it again! If an individual loses a chicken or a dog, he or she knows how to find it again; but the heart gets lost and he or she does not know how to look for it. Education serves us to do nothing else than to look for our missing heart." - A somewhat starker translation might read as follows: "When their dog or chicken is lost, they go looking for it, but when their heart-mind is lost, they do not bother." (2012, p. 2004).21) That education should exclusively consist of finding the missing heart or heart-mind represents a sharp turn. In my judgment, the passage translated into German is also remarkable for a number of reasons. First of all, education is more or less put on a level with xinxue. Secondly, according to Menzius, the problem does not consist primarily in not finding, but rather in not knowing how to look for it. Thirdly, education does not give the promise of finding the missing heart, but of being able to look for it again. This point of view and metaphor of education is not consistent and undisputed either, however: Idealistic (e.g. Wang Yan-ming, 1472-1529) and rationalistic (e.g. Chu Hsi, 1130-1200) tendencies in (Neo-) Confucian thinking differ from each other regarding the concept of education to a great extent. Accordingly, the role of knowledge and of obtaining knowledge is disputed. Some favor introspection, others the study of texts (cf. Reichenbach, 2018, pp. 181-197).

Of course, ideas of education seem to contradict each other occasionally. For example, it is possible to set Alfred North Whitehead's concept of education against the one by Confucius. Whitehead postulated three criteria for "sophistication," i.e. education (cf. Kann \& Sölch, 2012): mental activity, aesthetic receptivity, and sense of humanity. He held the belief that the process of education can only gain momentum and bear fruit through "romance." Without interest in the subject, any kind of knowledge

21) German version: "Pflicht ist der natürliche Weg des Menschen. Wie traurig ist es, wenn einer seinen Weg verlässt und nicht darauf wandelt, wenn einer sein Herz verloren gehen lässt und nicht weiß, wie er es wieder finden kann! Wenn einem Menschen ein Huhn oder ein Hund verloren geht, so weiß er, wie er sie wieder finden kann; aber sein Herz geht ihm verloren, und er weiß nicht, wie suchen. Die Bildung dient uns zu nichts anderem als dazu, unser verloren gegangenes Herz zu suchen”. 
acquisition is futile. The "stage of romance" is followed by the stage of "precision" and, finally, the stage of "generalization". According to Whitehead, any endeavor to advance in education is futile without interest for and emotional commitment to the subject. And it is easy to understand why. At the stage of romance, the subject matter still possesses the "vitality of the unprecedented" (ibid., p. 59). Here, the perspective for "the countless possibilities of connecting and re-contextualizing material and intellectual objects" (ibid., p. 28, transl. D. W.) is opened up. A cognitive but also emotional perception of objects is concerned. There is a lot of freedom but little discipline present. Freedom and discipline are not antagonists, they are rather thought as being in a natural pendular movement, "a back and forth" that corresponds to "the developing personality" (ibid., p. 75). "It is my firm belief that the cause for so many failures in the past is the lack of thorough studies of the appropriate status of romance. Without the adventure of romance, you will achieve, at best, passive knowledge without initiative and, at worst, contempt for ideas - without knowledge." (ibid., p. 78). ${ }^{22)}$ For Whitehead, the success of the Montessori Method of Education lies solely in the fact that the "dominance of romanticism" (ibid. p. 64) during childhood is fully acknowledged there. At the precision stage, the manifold experienced relations of a subject field are arranged and determined in greater detail; this is done by grammatical, logical, and mathematical structures and it is instructive "for a systematic continuation of the romantic gathering of facts" (ibid., p. 19). For Whitehead, it is literally "evident that a stage of precision is unproductive" without a previous stage of romance (ibid., p. 60). At the stage of precision, the students learn "to accept a predefined manner of analyzing facts little by little. New facts are added, but those facts are the ones that insert themselves into the analysis." (ibid.).23) It could be said that the stage of precision is centered on disciplining the mind for the most part. At the stage of generalization, finally, there is a "reaction towards romance"; ibid., p. 82, transl. D. W.) taking place now. This is the crucial stage; here, the mind is let free a bit at least, so to speak. At this stage, "the details are shaken off in favor of the active application of principles [...], whereby the details withdraw into unconscious habits"; ibid., p. 83, transl. D. W.). With the accomplished stage of generalization, the foundation is laid for

22) German version: "Es ist mein fester Glaube," so Whitehead, "dass die Ursache für so viele Fehlschläge in der Vergangenheit an dem Mangel an sorgfältiger Untersuchung des angemessenen Stellenwertes der Schwärmerei liegt. Ohne das Abenteuer der Schwärmerei wird man bestenfalls passives Wissen ohne Initiative erreichen, und schlimmstenfalls erreicht man Geringschätzung für Ideen - ohne Wissen".

23) German version: Lernen, "Stück für Stück eine vorgegebene Art des Analysierens von Tatsachen zu akzeptieren. Neue Tatsachen werden hinzugefügt, aber es sind diejenigen Tatsachen, die sich in die Analyse einfügen”. 
a new phase of romance and the cycle starts afresh.

In the discussions of Confucius (1979), however, there is an almost contradictory idea of education to be found. Learning seems to always give pleasure - at least to himself: "Is it not a pleasure to learn and to repeat and practice from time to time what has been learned?" (ibid., p. 59). If, strictly speaking, the idea of education is concerned in that case, the acquisition of knowledge and capabilities represents a condition of "love" - or of "romance" - for the object. The evaluation of the feelings' importance is, however, comparable: "To know [the Way] is not as good as to love it, and to love it is not as good as to take delight in it" (ibid., p. 84). Knowing and being able may come first, only then may the student begin to appreciate (or love) the subject of his or her knowledge of capabilities and to later relish - with increasing "mastery" - his or her knowledge and capabilities.

Which idea impresses more? Who is right? Confucius or Whitehead? Is it an empirical question? You would like to answer such questions with that it entirely depends on the situation, the person, the subject matter and so on - but why should you like to deny that romance could be the consequence of what has been acquired tediously before?

Ideas cannot be proven, however, they can help, as mentioned, to guide the cognitive process; they can open up perspectives and offer orientation for describing and understanding social, psychological, political, ethical, spiritual, and aesthetic phenomena. The natural and cultural world can made accessible through ideas, i.e. with ideas, perception becomes richer, deeper, more meaningful. "Caring for ideas" is an idea of education in itself - maybe a truly important and slightly forgotten idea of education.

\section{Conclusion: (Rather) Modest Ideas}

To attach absolute, universal, generally accepted claims of validity to political, ethical, or religious ideas seems no longer appropriate or even dangerous for a pluralistic and multicultural as well as economically globalized and increasingly digitalized world. To the ethos of the "crooked wood" or a civility or citizenry in line with the times belongs the demand from the individual not to let rigid impulses of truthfulness lead his or her actions and thoughts. The capability and the willingness to regulate emotions and domesticate behaviors certainly belong into this category. In decent societies (cf. Margalit, 1998), "you know" that it cannot or should not be that it is always and 
strictly about the idea or the ideal of what is good, beautiful and true, but rather about what is decent, pleasing, and appropriate, about socially acceptable arrangements under not-ideal conditions of human cohabitation, characteristic for the situation. For this reason, there is mistrust in decent societies regarding the fanatic search for truth and the swift discrimination of morally precarious behaviors.

Diverse people or groups of people who do not know each other for the most part and, therefore, do not understand each other - or also: do not understand each other, because they do not know each other - live probably better together, or side by side at least, taken as a whole if they do not let themselves being led by the imperative of authentic expression. Accordingly, it is part of a decent individual that he or she is not only anything but a truth monger, but also capable to turn a blind eye sometimes - not to drag everything into the spotlight. Sometimes it is apparently about the fact that certain things are better kept in the dark, sometimes it is about to present them in a certain and maybe not too bright a light. A "decent" individual knows, therefore, that the truth does not only enlighten but also destroy - and what it destroys is by no means only "false meaning," but it can also be productive or "positive illusions" (cf. Taylor, 1993), i.e. prejudices that make life more human. It appears to me that the assumption that complete impartiality (which is impossible, of course) would make the world more human is not able to provide sound reasons. According to the sociologist Karl Otto Hondrich, sometimes "the illusion of truthfulness has to give way to the normality of not-knowing and the twilight of discretion" (2002, p. 163).

Modest or rather modest ideas may, therefore, have a positive influence on a normal, everyday life as well. Thereby, the culturally underlying "great ideas" of what is good, just, or beautiful are not weakened in their regulative potential, but their destructive potential will be tamed hopefully.

\section{References}

Arendt, H. (1998). Vom Leben des Geistes. Das Denken. Das Wollen. Munich: Piper.

Berlin, I. (2001). Persönliche Eindrücke. Berlin: Berlin Verlag.

Berlin, I. (1990). The Crooked Timber of Humanity. Princeton: Princeton University Press. Confucius (1979). The Analects (Lun yü). Translated with an introduction by D.C. Lau. London: Penguin.

de Libera, A. (2005). Der Universalienstreit. Von Platon bis zum Ende des Mittelalters. 
Paderborn: Fink.

Flam, H. (2002). Soziologie der Emotionen. Konstanz: UVK Verlagsgesellschaft/UTB.

Foray, P. (2007). Autorität in der Schule. Überlegungen zu ihrer Systematik im Lichte der französischen Erziehungsphilosophie. Zeitschrift für Pädagogik, 53, 615-626.

Hondrich, K. O. (2002). Enthüllung und Entrüstung. Eine Phänomenologie des politischen Skandals. Frankfurt am Main: Suhrkamp.

Illouz, E. (2009). Die Errettung der modernen Seele: Therapien, Gefühle und die Kultur der Selbsthilfe. Frankfurt am Main: Suhrkamp.

Jaspers, K. (2013). Philosophie: II. Existenzerhellung. Berlin: Springer.

Kann, Ch., \& Sölch, D. (2012). Einleitung. In C. Kann \& D. Sölch (Eds.), A. N. Whitehead - Die Ziele von Erziehung und Bildung und andere Essays (pp. 7-35). Frankfurt am Main: Suhrkamp.

Kant, I. (1991). Kritik der Urteilskraft. Stuttgart: Reclam.

Kant, I. (1975). Die drei Kritiken in ihrem Zusammenhang mit dem Gesamtwerk. Mit verbindendem Text und zusammengestellt von R. Schmidt. Stuttgart: Kröner.

Lakoff, G., \& Johnson, M. (1980). Metaphors We Live By. Chicago: University of Chicago Press.

Leppin, V. (2007). Theologie im Mittelalter. Leipzig: Evangelische Verlagsanstalt.

Margalit, A. (1996). The Decent Society. Cambridge: Harvard University Press.

Menzius (2012). Menzius. Von der Freiheit des Menschen. Übers. von Richard Wilhelm. Wiesbaden: Marix.

Noddings, N. (1992). The Challenge to Care in Schools. New York: Columbia University/Teachers College Press.

Plato (1961). Der Staat. Hamburg: Felix Meiner Verlag.

Reichenbach, R. (2018). Ethik der Bildung und Erziehung. Paderborn: Schöningh/utb.

Rogers, C. (2007). Der neue Mensch. $8^{\text {th }}$ Ed. Stuttgart: Klett-Cotta.

Rogers, C. (2005). Die Person als Mittelpunkt der Wirklichkeit. $2^{\text {nd }}$ Ed. Stuttgart: Klett-Cotta.

Rogers, C. (1969). Freedom to Learn. New York: Merill.

Rogers, C., \& Freiberg, J. (1994). Freedom to Learn. $3^{\text {rd }}$ Ed. New York: Merrill.

Sebök, Z. (2008). Parasitäre Kultur. Berlin: Kadmos.

Taylor, Ch. (1985). Self-Interpreting Animals. In Ch. Taylor, Philosophical Papers, Vol. I: Human Agency and Language (pp. 45-76). Cambridge: Cambridge University Press.

Taylor, S. E. (1993). Positive Illusionen. Produktive Selbsttäuschung und seelische Gesundheit. Reinbek bei Hamburg: Rowohlt.

Tocqueville, de, Alexis (1987). Über die Demokratie in Amerika. Zürich: Manesse. 
Urmson, J. O. (1967). Ideas. In P. Edwars (Ed.), The Encyclopedia of Philosophy, Vol. 4 (pp. 118-120). New York: Macmillan \& Free Press.

von Humboldt, W. (1969). Werke in fünf Bänden. Band IV Schriften zur Politik und zum Bildungswesen. $2^{\text {nd }}$ Ed. Darmstadt: Wissenschaftliche Buchgesellschaft.

von Thadden, E. (2005, April 06). Die Igel der Welt. Die Zeit. Retrieved from https://www.zeit.de/2005/15/st-kakarneu.

Wilson, E. G. (2009). Unglücklich glücklich. Von europäischer Melancholie und American Happiness. Stuttgart: Klett-Cotta.

\section{Article History}

Received on July 21, 2019 / Revised on July 28, 2019 / Accepted on July 29, 2019 